\title{
Politics, Poetry, and Performance: The Miscellaneous Contents of Arbury Hall MS 414
}

Arbury Hall ms 414 is the bound volume which contains the four full-text plays addressed elsewhere in this special issue. As well as preserving these plays, this volume also includes other valuable literary material: unique stage directions for an Inns of Court masque, original verses to poems, and different variants for theatrical and poetic texts. ${ }^{1}$ While many of the articles in this special issue of Early Theatre deal with the texts of the previously unattributed plays and their literary and theatrical implications, this analysis concentrates on the physical contexts of the plays, that is, the texts surrounding the plays and the historical, political, and cultural forces that led to the creation of this volume.

Arbury Hall Ms 414 is a composite volume or aggregation, a collection of roughly thirty textually discrete manuscript items that were later bound together. ${ }^{2}$ As with most composite volumes, the pieces are in different hands on different papers, but this essay does not offer a thorough codicological or bibliographical description, much of which Margaret Jane Kidnie covers in her introduction to the Malone Society edition of the Arbury Hall version of The Humorous Magistrate. While I offer some paleographical comments on these texts, there is certainly more work to be done in this area with regards to this volume and others in the Newdigate archive. Rather, this paper follows Harold Love's advice about the study of composite volumes: 'the first goal of such inquiries should be to explain how certain works rather than others should have been brought together between a given pair of covers over a given span of time'. ${ }^{3}$ In her discussion of early English sammelbände (composite volumes), Alexandra Gillespie observes that there is often a very practical motivation for compiling a composite volume, not the least of which is because binding separate texts made a book sturdier and increased its longevity. Gillespie further argues that early composite volumes often have cultural significance and can indicate a compiler's tastes and thematic 
interests. ${ }^{4}$ This essay, then, analyzes the themes, ideas, and family interests revealed in Arbury Hall ms 414. While the volume includes works on topics that interested the Newdigates, it by no means offers only one opinion of current events or politics; like other early modern miscellanies and composite volumes A414 at times presents voices with which the compilers may not have agreed. ${ }^{5}$ The act of investigating individual manuscripts and families is microhistorical research, which focuses on the particular, rejects the description of the typical case, and yet, 'can serve to reveal more general phenomena. ${ }^{6}$ As a composite volume comprising multiple texts, Arbury Hall ms 414 points to a group of multilingual compilers in the Newdigate family who were interested in local, domestic, and foreign politics as they were represented in poetry, prose, and drama. Arbury Hall Ms 414 serves not only as an example of scribal publication, but as a demonstration of the collective creation of early modern manuscripts and the fluid nature of manuscript texts: manuscript compilers commented on, changed, and responded to existing texts while also adding texts of their own creation. ${ }^{7}$ Although, at first glance, the volume's disparate texts seem to be unrelated, I contend that they are bound by more than their covers: the poems, plays, and prose pieces in this volume are also yoked together by one family's interests in theatre and politics.

The covers of Arbury Hall ms 414 (also called the Newdigate volume) are a grey-blue binding from the eighteenth century that is approximately $15.5 \mathrm{~cm}$ wide $x 21.3 \mathrm{~cm}$ long. ${ }^{8}$ Kidnie proposes that the date 1782 on the endpapers is possibly the date of binding and Love reminds us that most aggregates are the creation of later generations of librarians. ' Kidnie's suggestion that this volume was bound in the late eighteenth century could very well hold true, although it seems unlikely that papers were added after the first decade of the eighteenth century, as no material included postdates the first decade of the eighteenth century. ${ }^{10}$ The composition, transmission, and compilation process for the items in this volume extends over a century and includes the activity of many: the large number of original writers who composed the texts or transcribed orally transmitted material; secondary scribes who re-copied some of the texts; unknown persons through whose hands many items passed before they arrived at Arbury Hall; and those at Arbury who read and gathered the texts. Finally, someone or some people had the text bound, no later than 1782. Rather than examining the texts in the context of their original creation, my focus is on the gathering stage of this volume's compilation, which leads us to consider who read and collected these works. 
I find that some of the works in the volume once circulated via scribal publication as separates, which are single texts or a gathering that circulated as an individual unit. ${ }^{11}$ Separates, which were often political texts, passed from person to person and readers often re-copied some or all of the separate into other manuscripts. ${ }^{12}$ Rather than copying the contents of these short manuscripts onto another sheet of paper or into a blank pre-bound manuscript, however, the compilers of the Newdigate volume gathered the physical separates. Some of these items may have been scribally published, which means that one person created or commissioned multiple copies. Thus, the contents of the Newdigate volume were not originally conceptualized as part of a larger work.

Before my discussion of the volume's contents, I would like to introduce the Newdigates whom I will argue were the compilers and sometimes copyists of the Newdigate volume. ${ }^{13}$ I contend that John Newdigate III (1600-42) was involved in creating this volume as an author, a copyist, and a compiler (see Appendix B for a clarification of the Newdigate family tree). Vivienne Larminie argues that John III authored the poem 'To a Poet Whose Mistris Was Painted' and that the version in this volume, dated 1637, is in his hand. ${ }^{14}$ Boyda Johnstone and Kirstin Inglis argue that John III also composed and copied all four of the full-text plays in this volume. ${ }^{15}$ Based on the hand found in these documents, I suggest that John also transcribed, and perhaps wrote, 'To a Poet Whose Mistris Was Painted', as well as copying Corbett's famous poem, 'Ive Read of Ilands Floating \& Removed'. ${ }^{16}$ John III was not only one of the authors of the material in the Newdigate volume; he also recopied other people's work. I argue that he also had a hand in collecting and gathering some of the papers that would later be bound into Arbury Hall ms 414.

A later contributor was John's nephew, Richard II (1644-1710), who was instrumental in gathering (and even commenting on) the papers collected in the Newdigate volume. When John III died in 1642 with no surviving children, his estate passed to his brother, Richard I (1602-78). ${ }^{17}$ Although Richard I may not have contributed much to this volume, it is reasonable to conclude that he was in possession of the material that would later become Arbury Hall ms 414 as well as other manuscript material that was not included in the miscellany. These documents passed from Richard I to his son, Richard II (1644-1710), whose political tastes inform much of the volume. According to Peter Beal's Catalogue of Early English Manuscripts, in 1702 the papers belonged to John Newdigate (1672-1705) of Gray's Inn and 
the Inner Temple, who was the grandson of Richard I and son of Richard II. ${ }^{18}$ After John's death in 1705 and his father's death in 1710, these papers remained in the Newdigate family collection. While Richard I and John (1672-1705) may have had input in the formation of this volume, John III and Richard II were the principal actors involved in collecting these items.

\section{Overview of Arbury MS 414 Contents}

Although examining Arbury Hall Ms 414 in sections can help us discuss the contents of this volume, it is important to remember that, while some of the sections are clearly delineated (such as the plays, the masque, and a collection of Latin poetry), other sections are less clearly defined. This sporadic organization system suggests that papers were at least (or best) cursorily organized before they were bound. Nevertheless, the binding itself demonstrates a degree of deliberate thought in connecting these texts. This volume, as with other composite volumes and miscellanies, requires cautious conjecture about editorial intention but also about the circumstances that drew these texts together.

For clarity, I discuss this manuscript in different sections. The first section of the volume (ff 1-12) is a separate, written in one hand, that contains an abridged version of The Masque of Mountebanks. The first and last pages, 1 and $12 \mathrm{v}$, are more worn than the rest, indicating that these pages were once exposed and therefore that the section had circulated unbound before it was bound into Arbury Hall ms 414. The second section (ff 13-37) comprises primarily prose political documents, including texts on English and continental politics. The Latin poem about Prince Joseph of Hungary (ff 36-7) offers a segue from the political material into the third section, a collection of Latin poetry (ff 38-49). Following the Latin poems is the most eclectic section of the volume: various poems written in multiple hands, including songs, libels, and bawdy poems (ff 50-75). Although the topics of the poems vary widely, some pointedly political themes run through the poetic texts assembled in this section of the volume. I consider the fifth and final section of the volume to be the four full-text plays, Ghismonda (ff 77-102), The Humorous Magistrate (ff 104-43), The Emperor's Favourite (ff 145-94), and The Twice Chang'd Friar (ff 196-end). These plays could each be considered as one unit, or the final three plays could be considered a unit because $\mathrm{f} 103$ is a title page that reads simply, 'Plays'. 


\section{The 1617/18 Gray's Inn Revels: or, The Masque of Mountebanks}

The first item collected in the Newdigate volume, 'The Style of Henry the Second Prince of Grayes Inne Anno Domini 1617' (ff 1-12), is an abridged version of the revels presented at Gray's Inn on Candlemas Day (2 February 1617/18), parts of which were later presented for King James and the court at Whitehall on 19 February. ${ }^{19}$ The revels as a whole are at times called The Gesta Grayorum Part Two, though this performance is not a sequel to the first and more famous 1598 Gesta Grayorum. ${ }^{20}$ This entertainment is also referred to as The Masque of Mountebanks (a title given by John Payne Collier), though the mountebanks are only part of a larger, multi-part revels that includes law sports (consisting of a proclamation, the swearing in of the Knights of the Order of the Crescent, humourous legal claims, and resolutions of amusingly debated judgments), the antimasque of mountebanks, another antimasque featuring Paradox personified, and finally, the masque proper, about dancing and singing knights who are released from their imprisonment. ${ }^{21}$

Though four extant manuscripts contain complete texts of the Gray's Inn revels - BL Add. ms 5956, Gray's Inn Library ms 29, Bodleian Rawl. D. Ms 1021, and Huntington Ms HM 21 - the Arbury version includes information that could not have been copied from one of these texts. ${ }^{22}$ None of these manuscripts, furthermore, can be regarded as more authoritative than another because they all stem from the same circles of manuscript transmission, and notably, they are all linked to Gray's Inn. The four full-text manuscripts begin with the mountebank's speech, 'The great Master of Medicine, Aesculapius preserve and prolong the sanity of these royal spectators'; they do not include the initial law sports and so could not be a source for the Newdigate version. ${ }^{23}$ John Nichols published a version of the revels from a manuscript in the British Library that is not currently catalogued and is now unlocated. ${ }^{24}$ While the now-lost Nichols manuscript does include the same opening law sports as the Arbury version, the Nichols manuscript could not have been a direct source because the Arbury version includes two 'masculine' paradoxes (paradoxes offered as advice to men by the character Paradox) not found in Nichols's version: 'Of all professions a Phisitian is the wisest for who is not a Phisitian is a foole' and 'He cannot be truly wise that was never Master of Arte for science is the mother of wisdome \& Accademies they are dry nurses. ${ }^{25}$ Of all manuscripts known to contain all or part of this entertainment, the verse 'Of all professions a Phisitian is the wisest' is unique to the Newdigate volume. ${ }^{26}$ 
The Arbury version is organized as follows: first, the abridged law sports; second, the note about the performance at court; third, three framing cantos; and fourth, the list of mountebanks followed by the mountebanks' songs and speeches. ${ }^{27}$ The law sports in the Arbury version conclude when the fictitious council resolves 'Certaine incertainties which have lately arisen concerning his highnes prerogative'. ${ }^{28}$ The complete antimasque of mountebanks is retained in this version. The Arbury abridgement concludes with the selections from the second antimasque of Paradox, in which Paradox himself offers epigrammatic one-liners such as 'A drunkard is a good Philosopher for he thinks aright that the world goes round' and 'A Cutpurse is the surest trade for his worke is noe sooner done but he hath his money in his hand'. ${ }^{29}$ This version of the entertainment highlights the legal and bawdy elements of the revels, while often eliding the romantic.

The Newdigate volume offers new information on the performance history, music, and audience of the 1617/18 entertainments because it contains descriptions of staging, notes about who attended the performances, as well as a new paradox from the antimasque of Paradox that are not found in other print or manuscript versions. The as-yet unpublished descriptions found in the Newdigate version alone emphasize the need for a new edition of the 1617/18 Gray's Inn revels, particularly one that highlights the differences between the two performances. ${ }^{30}$ Although a few scholars have briefly discussed these revels, the most valuable research to date (by Gabriel Heaton) remains unpublished. ${ }^{31}$ This entertainment (including the witness in the Newdigate volume) would benefit from further attention from bibliographers, literary critics, and theatre historians. I do not argue that the Newdigate volume should be a primary copy-text for these revels; nevertheless, the Arbury version includes elements that add to our understanding of the performances and should not be overlooked. ${ }^{32}$

The unknown source text for the Arbury version suggests four possibilities: the Arbury copyist used multiple manuscripts to write this version, at least one not now extant; the Arbury copy was made from a now-missing exemplar that included details of performance; the Arbury copyist had special knowledge of the performance to add missing details; or, perhaps least likely, the Arbury copyist participated in the collective authorship of this entertainment by adding an extra paradox after the performance. As short quips that could be easily memorized, the extra paradoxes could have been added from memory by the Arbury copyist. One of the full-length versions of the revels, BL Add Ms 5956, contains multiple versions of paradoxes labelled 
as masculine, feminine, and neuter, depending on the implied target of the verse. For instance, there are three versions of the masculine paradoxes (with many repeated paradoxes, but also variations between each list) in BL Add MS 5956. ${ }^{33}$ Before including the extra paradoxes, this manuscript notes that they 'wer read at Grayes Inn but left out at Court to avoyd tediousnes'. ${ }^{34}$ The Arbury compiler might have had access to multiple exemplars of the paradoxes, like the compiler of BL Add Ms 5956 clearly did.

Although Heaton argues that the incomplete nature of the Arbury version of the masque is probably due to a 'failure either in exemplar or copyist', the abridged nature of the Arbury copy could, I suggest, also reflect the compiler's taste: for some audience members and readers, the bawdy and legal antimasques may have had more appeal than the poorly-plotted masque proper. I contend that the Arbury witness of The Masque of Mountebanks offers valuable information about what both performances included (at Gray's Inn 'On Candlemas Day 1617' and later 'in the banquetting house at Whitehall before the King and the Prince on Thursday night in Shrove weeke the 19 of February Anno 1617') and about costuming, which further demonstrates the importance of this volume to theatre and literary historians. ${ }^{35}$

The way in which the Arbury version highlights the satirical and bawdy elements of the entertainment indicates one of the appeals this entertainment had for seventeenth-century audiences. This abridgement opens with 'The Style of Henry the Second Prince of Grayes Inne', whose humourously long title includes the sexual allusion to the 'viscount of the pleasant and fertile Countries of the greater and lesser Cunnilania and Midlerowe'. ${ }^{36}$ A414 continues with the first thirteen articles to be observed by the (fictional) Knights of the Crescent, such as, 'If any of you have vowed service to some greate and worthy Lady, then doe it honorablie not kissing her glove when you may kisse her bare hand, nor her bare hand when you may reach her lipps, nor kissing her lippes when you may doe her more knightly service. ${ }^{37}$ After the bawdy jokes in the opening law sports comes the equally coarse humour of the first antimasque. The mountebanks, for instance, sing,

Mayds of the Chamber or the kitchen if you be troubled with an Itching

Come give me but a kisse or two

Ile give you that shall soone cure you. ${ }^{38}$

The copyist also includes the mountebanks' 'ffamiliar Receiptes' (recipes), such as 'If any Lady be sike of Sullens shee knowes not where, let her take 
her a handfull of simples I knowe not what and use them I knowe not howe applying them to the parte grieved I know not where and shee shall be well I knowe not when'. ${ }^{39}$ For the Arbury copyist, the bawdy and funny paradoxes, songs, and recipes were worth retaining.

The version of the 1617 Gray's Inn entertainments (including The Masque of Mountebanks) in the Newdigate volume reveals a conscientious copyist interested in the entertainment for a number of reasons: its humour and appeal, its connection to Gray's Inn and the court, and its performance history. Importantly, the copyist intended to keep a record of performance, noting the differences between the two performances and including some descriptions of costume, staging, and music. ${ }^{40}$ While adding to our knowledge of performance history, the Newdigate volume will help later textual editors determine which elements were performed at Gray's Inn but not at Whitehall.

The Arbury version of this masque will further interest theatre historians because it offers more detailed descriptions of the event as it unfolded at court. Considered with Bodleian Rawl. D. Ms 1021 and Gray's Inn Ms 29, the Arbury version offers a fuller picture of when and how one set of songs in particular was sung - the framing songs, or those sung directly to the audience. The entertainment includes three of these songs: 'Welcome Grandees to You All', 'You Are the First of This Great Common Wealth', and 'Wee Whileome Thought $\&$ Thought Aright Our Sphere. ${ }^{41}$ According to the Bodleian Rawl. D. Ms 1021, the first song ('Welcome Grandees') was 'songe by the voyces to sixe Lutes' after the Prince saluted the singers; Gray's Inn Ms 29 adds that it was sung 'at the Lords first comming'. The Newdigate volume, however, adds that this was 'before they sate to meate. ${ }^{42}$ Both Bodleian ms Rawl. D. 1021 and Gray's Inn Ms 29 agree that the second song, 'You Are the First', was to be sung to the lord chancellor, Francis Bacon, in the middle of dinner. The Arbury copyist is even more specific, pointing out that the song came after the second course. ${ }^{43}$ Bodleian Rawl D. Ms 1021 and the Arbury version agree that the final song, 'Wee Whileome Thought $\&$ Thought Aright Our Sphere', was sung 'after Revells at parting. ${ }^{44}$

The Arbury version of these songs is important not only because it offers clarification on the ordering of the event, but also because of the placement of the songs. In the Gray's Inn manuscript, the cantos are appended to the end of the performance as an afterthought; in Bodleian Rawl Ms 1021, the cantos appear after the paradoxes. Two full-text versions of the revels, BL Add. Ms 5956 and the Nichols transcription, do not even include these three 
songs. The organization of the Arbury version, which places the songs before the antimasque, reinforces that law sports were not presented at court (as they precede the note about court performance). ${ }^{45}$ That the law sports precede the welcoming songs further suggests that the law sports were performed even before the guests of honour had arrived at Gray's Inn for dinner.

The Arbury version elaborates on the props the mountebanks carried: 'They sing their song having glasses, oyles, water $\&$ boxes $\&$ papers of powder etc which they showed in their songes. ${ }^{46}$ Another stage direction (unique to the Arbury version) offers a description of Paradox's costume: 'Enter Paradox in a wide sleeved gowne laid with white a suite layd all over with Cheavrons of blacke stockinges a Crooke Capp suteable. ${ }^{47}$ The descriptions of props and costumes in the Arbury version are not only valuable for our understanding of this entertainment's performance, but also for illuminating related texts and performances. For instance, Sarah Knight suggests that the mountebanks in Britania Triumphans could have worn similar costumes to the Gray's Inn's mountebanks. If this is the case, the detailed descriptions in the Arbury version add even more props to the decanter held by a mountebank in Inigo Jones's sketch. ${ }^{48}$ Certainly, other revels from the Inns of Court as well as other courtly entertainments and public plays (including many that feature mountebanks) can be reconsidered with the knowledge of costume and props provided in the Arbury version of the Gray's Inn revels.

As well as including descriptions that illuminate performance history, the Arbury version explains which 'honorable personages' were present in the audience at Gray's Inn. ${ }^{49}$ Bacon's presence as one of the guests of honour at the masque is well documented, but the Newdigate volume's list of audience members gives even further insight into who attended the Gray's Inn performance. ${ }^{50}$ The Newdigate volume records the presence of the new lord chancellor, Sir Francis Bacon; Thomas Howard, earl of Suffolk, lord treasurer; Edward Somerset, lord Worcester, lord of the privy seal; William Herbert, third earl of Pembroke, lord chamberlain; and James Hamilton, second marquess of Hamilton. Bacon himself was an alumnus of Gray's Inn; Howard had been honorary member of Gray's Inn since 1598. ${ }^{51}$

This abridged version of the Gray's Inn revels would have appealed to seventeenth-century readers with legal knowledge, with an interest in politics, with connections to Gray's Inn, and to those with a taste for plays and here, we return to the Newdigates. Both John Newdigate III and his younger brother Richard Newdigate I were entered into the pension books at Gray's Inn in 1620, less than three years after the performances of these 
revels. Richard continued at Gray's Inn, though John attended the Inner Temple. ${ }^{52}$ The separate including this abridged version of the revels (including, unlike many other versions, the law sports) might have appealed to John III, a budding playwright himself, or Richard I, a soon-to-be lawyer. In the 1620s and 1630s, we have evidence of John buying playbooks and attending plays and masques, as well as, in August 1633, purchasing a copy of Bacon's Advancement of Learning. ${ }^{53}$ Heaton suggests that the selections from the revels found in the opening separate of the Newdigate volume could have been copied specifically for John Newdigate III, and therefore would have been written in 1620 or 1621, when John was in London. I add that John's preferences could even account for the omission of the masque proper. Although we do not know the extent of his involvement in obtaining a copy of the Gray's Inn revels, John Newdigate surely can be considered as one reader (among many) interested in the drama performed at the Inns of Court.

\section{Political Prose: News and Opinions on Current and Past Events}

The selection of political tracts and political notes (in separates) that follow the masque reflect the seventeenth-century Newdigates' keen interest in politics. Love points out that by 1629 there was no shortage of separates containing parliamentary speeches and declarations: an example from the Newdigate volume is the Commons' petition of 9 December 1621 to James I. ${ }^{54}$ The separates in this section were originally written (and would have been of immediate interest to a reader) in the 1620s. While John III had returned to Warwickshire by 1621, Larminie demonstrates that he remained informed about domestic and continental politics throughout the 1620s and continued collecting speeches and pronouncements, sometimes copying them in his own hand. ${ }^{55}$ John was himself involved in politics, first as the sheriff of Warwickshire and later as part of the Warwickshire commission of the peace. ${ }^{56}$ The conjecture that John collected at least some of the political documents in this section of the volume is not unreasonable.

While we can conjecture that John gathered some of the political documents in this section, we have paleographical evidence that Richard II saw and read at least some of these documents. Larminie argues that the brief synopsis of one political tract about the thirty years' war is in his hand. 57 Entitled 'French Advertisements vpon the Present Estates of Germanie and Bohemia Anno 1620', Richard describes it thus: 'Perswading the french King rather to aid Frederick then Ferdinand: It seemes to bee written by a french 
Man no freind to the house of Austria'. According to one biographer, Richard II had a 'keen interest in home politics and foreign affairs, more especially in regard to France, a country for which he had a special distrust and dislike'. ${ }^{58}$ Although Richard's anti-French bias is not supported by this tract, his interest in international and national politics is particularly evident in this section of the volume and in the later political poetry.

The Newdigate volume also includes notes on the earl of Bristol's accusations against the earl of Clarendon. On 10 July 1663, the earl of Bristol attempted to impeach the earl of Clarendon, the lord chancellor, by accusing him of treason. A414 lists, in 'The heads of ye 14 Articells', 'Sale of Offices', for instance, and 'Conuerting publicke mony to his owne vse.'59 Samuel Pepys, the famed diarist, was also interested in this scandal and recorded a different list of highlights from Bristol's accusations. Pepys finds the event to be 'great news' that had London abuzz. ${ }^{60}$

Unlike John III and Richard II, Richard I did not (to our knowledge) write in the Newdigate volume, though at least one document would likely have been of great interest to him. Richard I's baronetcy may account for the presence of 'A Proiect for A Newe Dignitie Between Barrons \& Knights', a text outlining the creation of the baronetage, a rank between baron and knight, created by James I in $1611 .{ }^{61}$ As the document outlines, the newly-created baronets would help pay for James's war in Ireland with a thousand-pound fee, and in return, the baronets would be addressed as 'sir' and their wives as 'lady'. Richard I was created first Baronet of the Newdigate Baronetcy in 1677 , albeit reluctantly. ${ }^{62}$ It is possible that Richard or one of his heirs commissioned a copy of 'A Proiect for A Newe Dignitie' or that an acquaintance passed this document on to the Newdigates knowing it would be of interest to the family. One can imagine Richard refusing a copy of the document just as he initially refused the baronetcy in 1677; conversely, he could have gladly taken this document and used it when he wrote his letters attempting to refuse the title. ${ }^{63}$ Although the thousand-pound fee was waived for Richard, he did not want it to seem like he had paid for royal favour after having accepted office during the Commonwealth. ${ }^{64}$ Whether or not he was personally involved in gathering this page (actively, by commissioning a copy, or passively, by receiving the page and saving it), Richard I's baronetcy would have made this document of interest to the entire Newdigate clan.

Richard II or another later compiler shaped the texts so that the political tract on the thirty years' war is paired with a Latin panegyric about Hungarian royalty that segues into further neo-Latin poetry. The panegyric praises 
the restoration of a free Hungary and presumably refers to the coronation of Joseph I of Hungary on 9 December 1687. This 'Ecloga' (eclogue) is a Latin poem full of classical allusions that might have been gathered by the same compiler who chose to keep the Latin poetry following the political prose. The Latin panegyric poem on the topic of foreign politics provides a smooth transition to the clearly delineated section containing Latin poetry.

\section{Early Eighteenth-Century Latin Poems}

The collection of six neo-Latin poems and an introduction was clearly created to circulate as an independent whole. We find it as a verse miscellany within a composite volume, with a separate title-page announcing its contents: 'Exercitationes Poeticae | Habitae | Etonae Velatarum | Ad Nativitatem Christi'. ${ }^{65}$ The document is written in a single hand: a neat italic script slanted slightly to the right. These poems are fair copies with no corrections and plenty of white space in the margins and surrounding titles and attributions. The poems are individually attributed to eight contributors: John Parker, John Neale, Joseph Neale, J. Ludford, Richard Holme, W. Liptrott, John Foxcroft, and Samuel Baylie. ${ }^{66}$ Significantly, the early eighteenth-century Newdigate family (including Richard II and his son John) would have known at least one of the neo-Latin poets: John Foxcroft was the vicar of Nuneaton (where Arbury Hall is located) from $1700-1720 .{ }^{67}$

This section opens with a prose introduction by John Parker presenting these works as the first literary labours of the authors and ends with a 'Peroratio' (concluding speech) by Samuel Baylie. Although the poems were meant to circulate as a verse miscellany, a primarily literary form, the titles of the poems suggest the oratorical and performance-related nature of the works: the introductory 'Oratio', some titled 'carmen' (which can mean song or poem), and the formal 'Peroratio'. One poem is even written as a dialogue between two characters, Corydon (a common pastoral name) and Menelaus. The final line of Baylie's concluding poem bids the audience farewell and requests applause if the works deserve it. As with other early modern texts, these poems/songs/speeches blur the line between the literary and performed, as do the final full-text plays in the Newdigate volume.

The January 1702/3 date on Baylie's 'Peroratio' indicates that this section is one of the latest in Arbury A414 and may have been collected by Richard II or his son John. ${ }^{68}$ The Newdigate volume shows us that John III passed on 
to his family not only his papers but also his interest in play-texts and, in the case of these poems, literature by local and non-professional writers.

\section{Eclectic English Poetry}

The contents of the Newdigate volume were collected over a century of political turmoil in England when literate citizens expressed their concerns by writing, reading, and collecting a variety of political texts, including prose, poetry, and even song. The most heterogeneous section of the Newdigate volume is the collection of English poems that comes after the Latin poems from Eton and before the concluding plays. These poems vary in tone; in this discussion, however, I focus mostly on the political poems which reflect the view from late seventeenth-century Warwickshire. Although it is easy to assume that Richard II collected most of the political poetry because his diary confirms his deep interest in the subjects they address, his son John, being a London lawyer (of Gray's Inn, 1694 and Inner Temple, 1702), might have had similar interests.

'A New Song upon the Election at Coventry' combines a partisan message with the rollicking tone and attitude of a drinking song; this song reminds us of Richard II's (and his family's) investment in local politics. ${ }^{69}$ Coventry, a West Midlands city, is about ten miles from Arbury Hall, Nuneaton. The song describes the election of 'a Hales and a Gery' (Geary), two Tory politicians who were elected in Coventry in 1702 and again in $1705 .^{70}$ This song takes an anti-Whig stance:

Be merry my boys be merry

Good news to ye town now is come

The noise of a Hales and a Gery

Has struck the Phanaticks all dumb. ${ }^{71}$

Whigs were at times called Phanaticks, as in The Phanatick in His Colours: Being a Full and Final Character of a Whig. ${ }^{72}$ Though Richard II was himself a Whig, this would not have prevented him from gathering this song about local politics, and, indeed, perhaps about local contacts. Richard II invited many aristocrats to serve as godparents to his fifteen children, including a Lady Anne Hales, a member of the local Warwickshire gentry. ${ }^{73}$ Furthermore, Arbury A414 contains a tract attributed to a Mr. Geary of Barwell (ff 17-23), which is less than ten miles from Nuneaton. The Newdigates 
were connected to the Hales and the Gearys by proximity, regardless of their political opinions.

A number of the political poems in Arbury Hall ms 414 relate to those libels, lampoons, and political satires that poured forth at the end of the seventeenth century and were later published in the Poems on Affairs of State print miscellanies (first published 1689). ${ }^{74}$ Edmund Waller's Instructions to a Painter (shorter version 1665, longer version 1666) began a vogue for a style of poetry that registered unhappiness with governmental affairs couched in advice to a painter. The Newdigate volume contains two poems in this style: the first, known as 'The Second Advice to a Painter' (1666), is often attributed to Andrew Marvell. ${ }^{75}$ The four reprints in 1667 attest to the poem's popularity; at least forty-six copies of this poem survive in manuscripts dating from the late 1660 s through the early eighteenth century. ${ }^{76}$ I suggest the next 'advice to a painter' poem in the Newdigate volume is written in the same hand. 'Advice to a painter' poems were dangerous to own, yet the Newdigates gathered and preserved them. Three 'advice to a painter' poems began with the same first line, 'Painter once more thy Pencill reassume.' ${ }^{77}$ Mary Tom Osborne argues that the 'Painter once more' poem that appears in the Newdigate volume is referred to in a report in March 1670/71 about a bookseller convicted 'of circulating a scandalous pamphlet in ms called the "Advice to a Painter" in which their Majesties and many of the nobility were maligned' 78

Like the other Poems on Affairs of State, 'A New Littany for the Holy Time of Lent. 1688' was first published alone (1688) and later anthologized (1689, 1697). ${ }^{79}$ The Newdigate version of 'A New Littany' demonstrates that the Newdigate copyists did not copy from the later print anthologies. ${ }^{80}$ Rather, the Newdigate collector was taking part in the scribal and printed manuscript circulation of these poems that led to the later print publication. 'A New Littany' combines the bawdy humour of the selections from the Gray's Inn revels with the biting satire of the 'advice to a painter poems':

From all the Women we have Whor'd

From being bound to keep our word

From Civill Broils \& foreign sword

Libera nos Domine. ${ }^{81}$

The poet hopes 'That we have time before we dye, / To settle Church $\&$ Popery'. ${ }^{82}$ As Larminie pithily phrases it, Richard Newdigate II had a 
'Whiggish nose for popery'. ${ }^{83}$ In fact, in 1679, Richard II was dismissed from the Warwickshire commission of the peace for his Whiggish political views. ${ }^{84}$

The Newdigate volume also preserves a poem about the succession crisis that would have interested the staunchly protestant Richard II. 'In the Praise of Folly' satirically praises men who avoid politics:

Happy the man whose friendly want of wit Makes him for all things but contempt unfit Regardless of the <.> burthen of the State, he laughs att all who toil beneath its weight. ${ }^{85}$

The poem condemns ignorance and deplores that 'fools have fortune and success / while men of wit and parts find nothing less, / for they consider what is fit to speak', whereas 'the brisk fop ... / talks most and lowdest' even though he has 'least to say'. ${ }^{86}$ The speaker decides that to rise in social status, he will deny his books: 'I'll be as empty as the shallowst pate, / and then perhaps shall be as fortunate. ${ }^{87}$ At the poem's conclusion, when the speaker has cast off political engagement for monetary and social success, he criticizes those who still try to 'rudely pry' into his 'royall brothers mind' that is, the mind of the future James II. ${ }^{88}$ The underlining of 'royall' draws the reader's attention from the poem's general condemnation of those who are not politically engaged to a specific criticism of the heir to the throne, James. ${ }^{89}$ King Charles II's brother and heir, James was a Catholic and in 1679 and the years following, the House of Commons attempted to disinherit him. The tone continues in a discussion of James's royal thoughts, which hold 'a secret too divine' (Catholicism) that is 'too sublime for vulgar scrutinies. ${ }^{90}$ Just as this poem facetiously advocates ignorance, the satiric tone continues in the discussion of James, implying that James's religion is a matter of public importance that ought to be considered and discussed.

Richard II collected many political newsletters from 1674 until his death in 1710; however, there are none extant from 1685, the year when Charles II died, James II became king, and two rebellions occurred (one in England, the Monmouth rebellion, and one in Scotland). ${ }^{91}$ Possibly he destroyed them because they were filled with sensitive information. ${ }^{92}$ The political tone of 'In the praise of Folly' implies that Richard II's 1685 newsletters may have been too dangerous to preserve, and more dangerous, even, than the 'advice to a painter' poems: they were probably highly critical of King James II, if not downright treasonous. 
The political poetry reflects not only Richard II's political and religious leanings, but also his distrust of the French. A patriotic love of England pairs with anti-French sentiment in 'The freeborn English generous and wise' (sometimes called 'An Allusion to Tacitus' by other seventeenth-century manuscripts and modern editors), a political broadside that was also later printed in a Poems on Affairs of State volume. ${ }^{33}$ This poem, sometimes attributed to John Wilmot, earl of Rochester, ${ }^{94}$ takes the premise that Englishmen will pay fair taxes but will not accept tyranny, unlike the French. The poet proudly proclaims, 'Here Power by Tyranny was never gott', unlike in France, which grows proud 'beneath their Tyrants Lust'. 95 The Newdigate version includes an interesting variant of the second line: rather than hating chains, the 'freeborne English' in this version 'Hate change'. ${ }^{96}$ Keith Walker and Nicholas Fisher date this poem's composition to 1679 or 1680, the time of the exclusion crisis about James II ascending to the throne. ${ }^{97}$ The variant found in the Newdigate version of this poem heightens the anti-Catholic sentiment of the poem: at the time this poem was written (and possibly when it was gathered), many of the English feared that Charles would die and leave the throne to a Catholic, thus bringing unwanted 'change' to England.

Despite his distrust of Catholics and the French, Richard II might have collected the volume's only French poem. This poem, 'Vers Envoyes de Paris sur l'entrée de My Lord Portland' ('Verses Sent from Paris About the Entry of My Lord Portland'), which begins, 'Cette Ambassade si celebre', describes Lord Portland's entry to Paris on 9 March $1698 .{ }^{98}$ Richard himself visited France in July and August 1699, shortly after these verses were written. ${ }^{99}$ The Newdigate volume's political poetry is of particular importance because it can allow us a view of politics in the Midlands while also demonstrating, as in the case of 'Cette Ambassade si celebre', the transmission of such works, even across the Channel. Whether Richard II picked up this poem while in France or later obtained a copy after his return, he was certainly not sheltered from the latest political and even celebrity news.

By collecting and binding disparate materials, the Newdigates preserved what might otherwise have been lost, just as Pepys and Robert Harley, earl of Oxford, did by binding and preserving printed ballads. One such libellous ballad, 'The Old Man's Wish', was printed multiple times in broadside and later collected in a Poems on Affairs of State volume. ${ }^{100}$ The Newdigate volume does not contain 'The Old Man's Wish' itself, but instead includes an additional verse to the ballad that circulated in manuscript in London in November $1685 .{ }^{101}$ In the case of the version of the poem in the Newdigate 
volume, this verse circulated alone, with just a reference to the popular ballad by title and chorus. The verse expresses a disdain for politics:

May I live far from Torys \& Whigs of ill Nature

But farthest of all from a Sly Observator

May it ne're be my Fate to Scribble for bread

Nor write any longer then Wise men will Read

May I Govern \&c. ${ }^{102}$

The 'Sly Observator' is a reference to Roger L'Estrange, whose anti-Whig newspaper, The Observator, was published from 1681-87. ${ }^{103}$ L'Estrange was known as 'the scribbler general of Tory-land', ${ }^{104}$ a status mocked in the additional verse in the Newdigate volume, 'May it ne're be my Fate to Scribble for Bread'. ${ }^{105}$ The chorus of the ballad, which is referenced in the additional verse, repeats the wish, 'May I govern my Passion with an absolute Sway / And grow wiser, and better, as my Strength wears away'. ${ }^{106}$ This earlier call to moderation is given a decidedly Whiggish slant in the additional verse found in the Newdigate volume that could have appealed to Richard II. Considering some of the more vituperative attacks on L'Estrange ('Despised by all, who have the least pretence / To Wit, to Business, Learning or good Sense'), ${ }^{107}$ the 'Addition to the Old Man's Wish' is a tamer taunt than many.

The Newdigate volume, particularly the 'Addition to the Old Man's Wish', exemplifies the scope and attraction of the libels and a power that L'Estrange recognized. L'Estrange actively sought to prosecute the publisher of Marvell's 'Directions to a Painter. ${ }^{108}$ He knew that manuscript publication of libels was, if anything, more dangerous than print circulation, as manuscript libels were much harder to censor:

The Question of Libells extends it self (I conceive) to manuscripts, as well as Prints; as being the more mischievous of the Two: for they are com[m]only so bitter, and dangerous, that not one of forty of them ever comes to [the] Presse, and yet by [the] help of Transcripts, they are well nigh as Publique. ${ }^{109}$

The Newdigate volume, like the dozens of other manuscripts that contain the 'advice to a painter' poems and others that would be printed in the Poems on Affairs of State volumes, proves L'Estrange's fears to be well-founded: the instance of this additional defamatory verse found in the Newdigate volume is one version of the poem that circulated in manuscript beyond London and proved to last longer than any broadside version of the poem (if one ever 
existed). Although Anthony Wood claims that this ballad circulated widely, the Newdigate volume is one of only three known manuscripts that include this verse. ${ }^{110}$

Indeed, the Newdigate volume preserves poetry that would otherwise be lost, including a possibly unique additional verse to William Cartwright's 'November.'11 The poet reminds his readers of major historical events that happened in November, such as the Gunpowder Plot (5 November 1605) and Princess Mary's birth (4 November 1631). The poem concludes by criticizing Charles I (who was king in 1647 when the poem was first published, and who was born on 19 November 1600), 'The last extreme against the First wetll bring / That gave us many Tyrants, This a King. ${ }^{112}$ After the traditional conclusion to the poem, the scribe wrote the initials W.C. to signify Cartwright's authorship. The copyist for the Newdigate version then added an additional verse - it was not uncommon for manuscript compilers to change or respond to the poems they copied. ${ }^{113}$ The new concluding verse celebrates Queen Catherine's birthday, 25 November 1638:

Another Queen O bless'd Conclusion!

Great Mary shall not go alone

Prepare the Altar, let the tapers shine

Try lustres with St Catharine

The Feast is double give both Saints their due

She is Old Stile, Ours is the New.

Come from thy curtains the pale tents of death

Revive us with thy verdant breath

And henceforth let thy glorious person feele

The Martyr's Coronet, but not her Wheele. ${ }^{114}$

The marginal notation explains 'Queen Catharine borne on St Catharines day, and recovered on the same'. ${ }^{115}$ Catherine did not become queen until she married Charles II in 1662, and the recovery mentioned in the poem possibly refers to her serious illness in 1663 , which demonstrates that the final verse was added after the Restoration and well after Cartwright died. ${ }^{116}$

While Richard II's hand is most evident in the political poetry in this section, the few not overtly political poems seem to point more to John III's involvement. John's own poem, 'To a Poet Whose Mistris Was Painted' and other poems he may have copied (including the popular 'Dr Corbet To ye Duke of Buckingham') are in this section. John Newdigate III and his younger brother Richard I were probably involved in gathering some of the 
earlier items, such as 'Mr Brownes Lettres to his Sweet Harts Mother'.117 As the marginal note explains, Mr Brown was a fellow of Trinity College, Oxford in 1618; both John III and Richard I matriculated from Trinity College in 1618.

'To a Poet Whose Mistris Was Painted' is certainly not in the tradition of the 'advice to a painter' poems; rather, it is about women, make-up, and deceiving exteriors. Since, as Larminie argues, this poem was written by John III, I include it in its entirety:

To a Poet whose Mistris was painted.

[Vpon a painted gentlewoman.]

August. 1637.

[Henceforeth forbeare] 'It is not safe' to call your Mistris faire,

Or to aknowledge, that your fancies are

Short to commend her, least you doe belye

Your bitter knowledge, \& your conscious eye.

You used to stand to't, that the choicest paint,

Lookt on when she stood by, appear'd so faint

That the best colour rather seemd a foyle

To sit here off, then any way to soyle

Her cleare cheekes by compare; vermilion die

Lookt like red oker, in her company,

And all the lustre, that it had, it tooke

From the faire rose in her serener looke.

You striu'd to faine what was not, or the case

Is, now, much alltred; her distrustfull face

Will not be seene abroad, vntill it be

Besmeard with red, like arras imagerye;

She has her severall boxes to select

Which she most needs, \& likes, for her defect;

And layes it on like puttie, which (they say)

The painters use to fill vp a decay

In poaste which time, or wind, hath chopt. The die,

She sayes [smells too much of] 'tends too much to' hipocrisie,

Therefore shee'l have it thick, that't may appeare

[That] 'Both' colour, [but] ' $\&$ ' that in which it doth inhere;

That all her earnest votaries may say

They worshipp substance, when they come to pray,

And sight is not deceau'd. St Francis glass 
Shall not returne her paramour an ass,

And bid him trust his faith. She will admit

[You] 'Him' both to see, to kiss and handle it,

But not to wipe or rubb. It is enough

[You] 'Hee' see the colour, and doe feele the stuffe

Which is both moist, and soft; If want of skill

Hath spoiled the colours, $\wedge$ 'by' layering on 'em ill,

Vpon her face, fitter for poast or gate,

Her woman's will hath wrongd hir female State.

Whose glorie is to be as she was made

Without black patches help or pencills shade ${ }^{118}$

And now she's not the painters shame, but is

Her owne, because she drew her selfe amiss. ${ }^{119}$

John III wrote this poem in the tradition of anti-cosmetic texts, such as Jonson's 'Still to be neat' from Epicoene. ${ }^{120}$

John's involvement in writing, copying, and gathering the poetry in this volume probably also extends to a version of 'When First King Arthor Rul'd This Land', a nursery song which relates directly to The Humorous Magistrate, one of the full-text plays that conclude the volume. In The Humorous Magistrate, Mistress Mumble sings a line 'Now lawyer I defie thee doe thy worst'; the Osborne manuscript offers detailed stage directions: 'she wipes her mouth sings the next line / to the tune of K. Arthur. ${ }^{121}$ Paul Faber convincingly argues that the ballad in The Humorous Magistrate is based on 'The Noble Acts of Arthur of the Round Table', a ballad that was much-adapted and often sung on the early modern stage; 122 'When First King Arthor' might be a parodic version that shares the same tune. Although this is not the ballad Mistress Mumble quotes directly, the allusion to a King Arthur poem in The Humorous Magistrate might explain why it was gathered with these materials. John might have saved a ballad that interested him, just as he might have included a familiar tune in his play. Alternatively, a later compiler might have collected 'When First King Arthor', thinking it related to The Humorous Magistrate. ${ }^{123}$

The final poem before the volume's concluding full-text plays is titled simply 'The Satyr's Complaint'. It begins, 'Tell me, O Nymph, why do you / Shun us, that your Loves pursue'.124 'The Satyr's Complaint' is associated with John Davies's The Entertainment at Harefield (performed 1602), which further reinforces the theatrical elements of this composite volume. A version 
of the entertainment is in fact preserved in the Newdigate archive and John Nichols published a version of The Entertainment at Harefield from the Newdigate papers in 1821 that included 'The Satyr's Complaint' as a finale for the entertainment. ${ }^{125}$ Heaton convincingly argues that the complete version of this entertainment in the Newdigate papers was tailored specifically for the Newdigate family. This production would have been of special interest because the Newdigates owned the Harefield estate until 1586 and recovered it in the 1670s. ${ }^{126}$ While modern editors and scholars agree that the 'The Satyr's Complaint' is distinct from the entertainment, the complaint is nevertheless associated with the entertainment in the version found in the Arbury archives, which is titled on the reverse of the complaint, 'Entertainment of Q. Eliz'. ${ }^{127}$ A Newdigate compiler might have recognized the complaint as relevant both to their family and to performance and so chose to include this particular text in Arbury Hall ms 414.

\section{The (Not-So?) Miscellaneous Contents of Arbury Hall MS 414}

Upon initial consideration, the Newdigate volume seems to live up to the nebulous genre of composite miscellany: it contains miscellaneous works that refer to a century of politics in both England and the continent alongside complete plays and lusty poems (such as Prior's 'Pallas and Venus' and the anonymous 'Satyr's Complaint'). When we consider Richard II as one of the compilers of the Newdigate volume, however, the seeming incongruity of the contents begins to fade; the Newdigate newsletters that Richard II received were not only filled with political news, but also included updates from the London theatre scene. ${ }^{128}$ Further, if we further consider this composite volume as the work of not one single compiler, but rather, as a collection of documents gathered by multiple individuals, the miscellaneity seems not only understandable, but expected. The miscellaneity of this volume, however, does not minimize its importance - the volume deserves attention precisely because it juxtaposes such varied pieces. Jeffrey Todd Knight reminds us that 'works were assembled — and, scholars have shown, imagined - in flexible, anthology-like formats that do not always map onto modern categories. ${ }^{129}$ The Newdigate volume can not only lead us to new understandings of the plays it holds but can also reveal the significance of the contents for real individuals in specific historic moments.

Arbury Hall ms 414 contains and at times merges the political and the theatrical. At times, the theatrical is the political in this volume, as Siobhan 
Keenan's analysis of The Emperor's Favourite and Mary Polito and JeanSébastien Windle's analysis of The Humorous Magistrate demonstrate. ${ }^{130}$ By presenting in their literary and historical context the material that precedes the four plays in the Newdigate volume, this article offers some possible frameworks for future research. Because the full-text plays have been bound with later items and poems with a decided emphasis on late seventeenthcentury politics, the plays in this volume should be read not only in relation to their original political settings, but also with an eye to the political significance they may have accrued in the tumultuous period of the civil wars, the interregnum, the Restoration, the exclusion crisis, and the Glorious Revolution. The plays in this volume are, furthermore, examples of the 'precious few' manuscript plays that we have: they demonstrate that manuscript plays at times remained in family hands (such as those composed by John III) whereas at other times they were recopied (evidenced by the Arbury and Osborne versions of The Humorous Magistrate), circulated, and changed (like the Grey's Inn revels). ${ }^{131}$ The items in A414 demonstrate that the Newdigate family participated in a culture, or, at least, a coterie, that circulated a wide variety of texts, including those that they wrote themselves.

Indeed, the miscellaneity of this volume represents the social and collective nature of textual transmission in the early modern period: the creation of this volume involved not only the Newdigates (and perhaps others) who gathered the papers, but also those who authored the multiple and varied texts, those who copied and recopied them, and those who read them as they circulated. As a collection of the theatrical and the political, the bawdy and the idealistic, the poetic and the functional, the Newdigate volume reminds us that members of the English country gentry could diligently follow current events and had a taste for the arts. While opening up new avenues for understanding its plays, the Newdigate volume highlights the specific political, historical, theatrical, and artistic tastes of one Warwickshire family. 


\section{Appendix A: Contents of the Arbury Hall MS 414, the Newdigate volume $^{132}$}

\begin{tabular}{l} 
folio(s) \\
\hline $1-12 \quad$ Title: 'The Style of Henry the Second Prince of Grayes Inne Anno Domini \\
1617' \\
Opening: 'The high and mightie Henry the Second by the free election ...' \\
An abridged version of the 1617/1618 Gray's Inn revels, sometimes called Gesta \\
Grayorum, Part II or The Mountebanks Masque.
\end{tabular}

13-14 Title: 'To the Kings Most Excellent Maiestie'

Opening: 'wee your most humble \& loyall subiects, ye knights, citizens, \& burgesses ...'

The Commons' Petition of 9 December, 1621

Mislabelled in a later hand 'A remonstrance from the Commons to King Charles ye $1^{\text {st }}$ Petition and Advice'.

15-16 Uncut blanks

17-23 Title: 'A Character of an Anabaptist' attributed to 'Mr. Geary of Barrwell' Opening: 'There is an Harlott with a painted face ...'

24 Title: 'A Proiect for A Newe Dignitie Betweene Barrons \& Knights; in which these circumstances are to be considered: viz.'

Opening: 'The partye shall beare the name of Barronett.'

25 Title: 'The Heads of ye 14 Articells Exhibited Against the Chancellor 10 ${ }^{\text {th }}$ July: 1663 per Earle of Bristoll'

Opening: 'espousing the King for intending an Introduction of poperry'

26-34 Title: 'French Advertisements vpon the Present Estates of Germanie and Bohemia Anno 1620'133

Opening: 'Without Spending time on that so well knowne to all'

36 Title: 'In Restitutam Hungariæ Libertatem; et Fælicem Illustrissimi Principis Iosephi Inaugurationem Ecloga'

First Line: 'Dicite Pierides Carmen, quod rusticus Ægon'

38-49 Title: 'Exercitationes Poeticæ Habitæ Etonæ Velatarum Ad Nativitatem Christi 1702 ' (sic)

A collection of Latin poems attributed to John Parker, John and Joseph Neale, J. Ludford, Richard Holme, W. Liptrott, John Foxcroft, and Samuel Baylie

50-55 First Line: 'Nay Painter, if thou darst, designe that fight'

Title of Separate: 'Second Advice to a Painter'

Poem often attributed to Marvell

56-57 First Line: 'Painter, once more thy Pencill reassume'

Title of Separate: 'A Lampoon'

Poem known as 'Further Advice to a Painter'

Poem sometimes attributed to Marvell 
Appendix A (continued)

58-59 Title: 'November'

First line: 'Thou sun that shewest the dayes, looke down and see'

By William Cartwright (attributed W.C.)

60 Title: 'Vers Envoyes de Paris sur l'Entrée de My Lord Portland'

First Line: 'Cette Ambassade si celebre'

61 First Line: 'When First King Arthor Rul'd This Land'

Traditional nursery song

62 First Line: 'The Trojan Swain had judg'd ye great Dispute'

Often titled 'Pallas and Venus'

By Matthew Prior

63 Title: 'A New Littany for the Holy Time of Lent. 1688'.

First Line: 'From all the Women we have Whor'd'

64 Title: “'Addition to the Old Mans Wish” If I Live to Grow Old \&c'

First Line: 'May I live far from Torys \& Whigs of ill Nature'

65 Title: 'Mr Brownes Lettres to His Sweet Harts Mother. Fellow of Trinity College in Oxford 1618'

First Line: 'I have sent here by this (Rascall)'

66 First Line: 'The freeborne English generous and wise'

Often titled 'An allusion to Tacitus'

Often attributed to John Wilmot, earl of Rochester

67 Title: 'In the Praise of Folly'

First Line: 'Happy the man whose friendly want of wit'

68v Title: 'To ye Lady Jane Smyth'

Draft of letter

69 First Line: 'Be merry my Boys be merry'

Title: 'A Song at the Election in Coventry' (attributed by archivist)

70 Title: '[Upon a Painted Gentlewoman]'

'To a Poet whose Mistris was painted' Aug. 1637

First Line: '[Henceforth forbeare] It is not safe to call your Mistris faire'

By John Newdigate III

71-72 Title: 'Dr Corbet To ye Duke of Buckingham'

First Line: 'Ive read of Ilands floating \& removed'

73-74 Title: 'A Dream of Elisium'

First Line: 'As in A Cypress grove beneath ye shade'

75 Title: 'The Satyrs Complaint'

First Line: 'Tell me, O Nymph, why do you'

77-102 Ghismonda (title attributed by T.H. Howard-Hill)

103 Mostly blank page, reads 'Plays' in upper right hand corner 


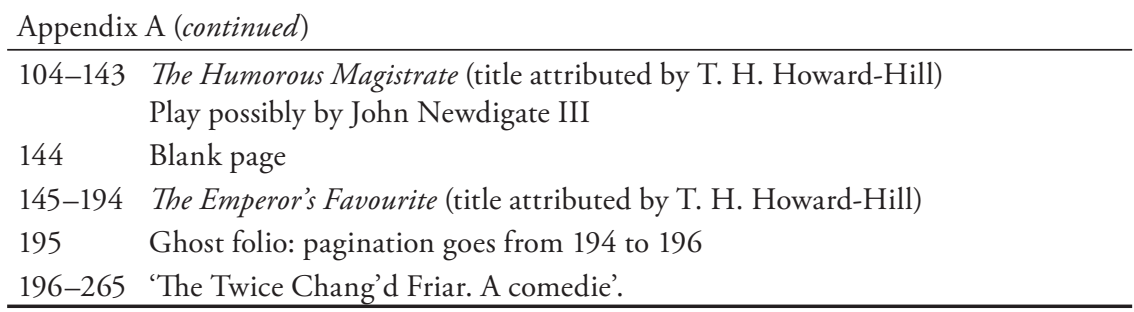

\section{Appendix B: Highly Selective Newdigate Family Tree ${ }^{134}$}

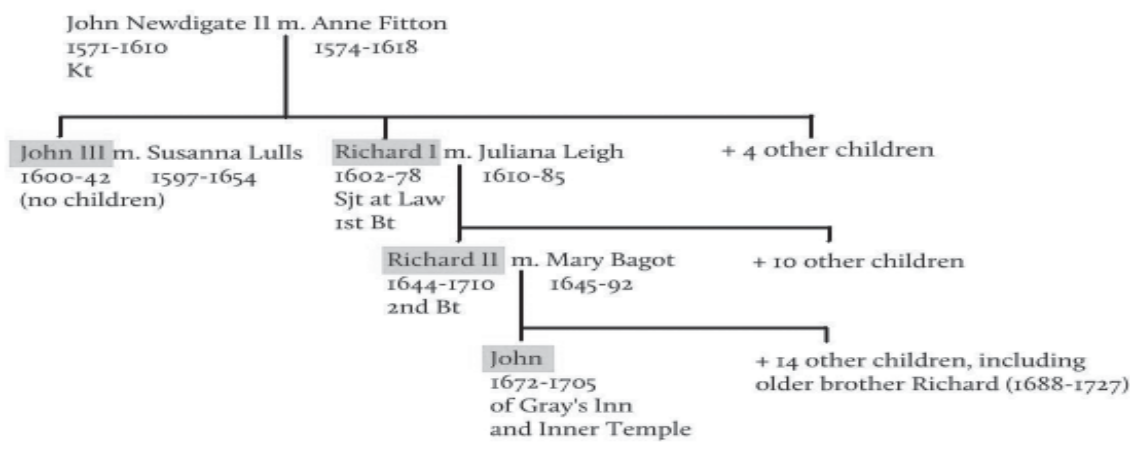

Highlighting denotes individuals who probably had a hand in compiling Arbury Hall ms 414.

\section{Notes}

I would like to thank Mary Polito for providing access to previous research about the miscellany and images of the miscellany itself, as well as for her thoughtful suggestions. I am also grateful to M.J. Kidnie, Alan Nelson, Gabriel Heaton, and Paul Faber for sharing their unpublished research and works-in-progress. I would also like to thank Andrea Silva, Renuka Gusain, and Kailin Wright for their keen eyes and helpful suggestions. A final thank you to all of those who have worked on the Arbury Osborne project and shared their work, including Boyda Johnstone, Kirsten Inglis, John Siddons, and Owen Stockden.

1 These interesting features will be discussed at length in the article, but they include a new verse for William Cartwright's 'November', verses and stage directions for the 1617/1618 Gray's Inn revels (The Masque of Mountebanks), as well as alternate 
readings for some poems, including 'In the Praise of Folly' and 'The Freeborne English'. The transcriptions for this article use REED notations, though the capitalization has been normalized according to Early Theatre's standards.

2 For a complete list of the manuscript contents, see Appendix A. I count poems as textually discrete when they are written on different papers. Peter Beal defines a composite volume as 'distinct from a compilation or a miscellany'; it is 'a volume made up of various physically and textually independent units bound together: e.g. a volume of separate papers or pamphlets'. While a miscellany is, according to Beal, still a 'mixture of literary compositions, of different genres or by different authors', it is a manuscript where the contents are copied by the compiler(s). Harold Love calls 'a volume formed by binding together material of diverse bibliographic origin' an aggregation, another term for composite volume. Calling Arbury Ms 414 a composite volume (or aggregation) accurately reflects how the volume was written and gathered. Using the term 'miscellany' or even 'composite miscellany' is less precise and could be, at times, misleading. See Beal, A Dictionary of English Manuscript Terminology, 1450-2000 (Oxford, 2008), 85, 255; and Love, The Culture and Commerce of Texts: Scribal Publication in Seventeenth-Century England (Amherst MA), Rpt. of Scribal Publication in Seventeenth-Century England (Oxford, 1993), 343.

3 Love, 'The Work in Transmission and Its Recovery', Shakespeare Studies 32 (2004), 74.

4 Alexandra Gillespie, 'Poets, Printers, and Early English Sammelbände', Huntington Library Quarterly 67.2 (2004), esp. 203-4.

5 As Sasha Roberts explains, early modern miscellanies were often based on dialogic reasoning; see 'Women's Literary Capital in Early Modern England: Formal Composition and Rhetorical Display in Manuscript and Print', Women's Writing 14 (2007), 246-69.

6 Giovanni Levi, 'On Microhistory', Peter Burke (ed.), New Perspectives on Historical Writing, 2nd ed. (Cambridge, 2001), 97-119, esp. 99, 113. Levi further explains that microhistory 'takes the particular as its starting-point ... and proceeds to identify its meaning in the light of its own specific context' (110).

7 The Newdigate volume offers a concrete example of the audience for works published scribally and demonstrates the afterlife of works published scribally: it shows where scribally published texts could end up if they survived at all. See Love, Culture and Commerce of Texts, 47.

8 See Kidnie's Introduction, The Humorous Magistrate [Arbury Edition], Malone Society (Manchester, 2011). She notes that two pages are so large that they have been folded to fit in the covers: 'A proiect for A newe dignitie' (f 24) and 'The freeborne English generous and wise' (f 66). 
9 Kidnie, Introduction; Love, Scribal Publication, 343-4.

10 One archivist (that Kidnie suggests misread the 1782 date as a shelfmark) included a note attached to a separate table of contents that suggests the manuscript might even have been bound in the early seventeenth century.

11 Love, Culture and Commerce of Texts, 13. Beal explains that a separate is 'a manuscript or printed text produced or issued as a physically independent unit, rather than being part of a larger entity or book' (Dictionary, 375).

12 Beal's example of a common kind of political separate is 'a Restoration lampoon written or printed on a single leaf or bifolium and circulated in this form' (Dictionary, 375). One such example in the Newdigate volume is 'Further Advice to a Painter' (which will be discussed at more length): the separate is titled 'A Lampoon' (f 57v).

13 When I discuss copyists or scribes, I am referring to those whose hands appear in the volume, whereas the compilers are those who gathered the already-written materials and had a more figurative hand in the compilation. At times, copyists and compilers are one and the same, but not always.

14 Newdigate volume, f70. For Vivienne Larminie's convincing attribution of both the poem and John's handwriting, see Wealth, Kinship and Culture: The 17th-Century Newdigates of Arbury and Their World (Suffolk, 1995), 173. This poem does not appear in any of the manuscripts or printed books catalogued in the Folger Shakespeare Library's Union First Line Index of Manuscript Verse, comp. Carolyn W. Nelson, firstlines.folger.edu.

15 See “"The Pen Lookes to Be Canoniz'd”: John Newdigate III, Author and Scribe' in this volume. It is also worth noting that the poem 'A Dream of Elisium' is signed 'Newdigate', and on the back of the poem there is a scribbled signature, 'John'. 'A Dream of Elisium' (f 73 ) is in a different script than 'To a Poet Whose Mistris Was Painted' (f 70), which could suggest multiple copyists. Johnstone and Inglis convincingly argue, however, that John III's hands (both italic and secretary) evolved over the course of his life, so perhaps we should consider that John III may be the 'John' and/or 'Newdigate' who signed 'A Dream', keeping in mind, of course, that the poem could have been signed after it was copied.

16 Newdigate volume, f 71-2.

17 Even though John had bequeathed his books to Gilbert Sheldon, later Archbishop of Canterbury (Howard-Hill, 'Another Warwickshire Playwright', 60), these papers did not pass with John's books to Sheldon (perhaps precisely because they were still unbound at that point; they might not have been considered a 'book').

18 Peter Beal (comp), 'Shelfmark Report / Viscount Daventry, Arbury Hall [long version], CR 136/414', Catalogue of Early English Manuscripts, forthcoming online. 
Though Richard II could have passed these materials to his elder son, Richard III (Dick), he instead chose to give them to John (Jack), possibly because of John's involvement with Gray's Inn and his interest in the subject matter. Anne Emily Garnier Newdigate-Newdegate, in Cavalier and Puritan in the Days of the Stuarts (London, 1901), explains the rift between Richard II and his son Richard III dating from around 1700, which might explain why Richard II did not give these papers to his eldest surviving son; see esp. 343-9. John's relationship with his father, however, was not always ideal, either: a list that Richard II wrote detailing his son John's faults is extant (Newdigate-Newdegate 298-9).

19 Newdigate volume, $\mathrm{f} 1$. The masque was scheduled to be performed for the court at Whitehall on 16 February 1617/18, though it was postponed until 19 February 1617/18; see Gerald Eades Bentley, The Jacobean and Caroline Stage: Plays and Playwrights, vol. 5 (Oxford, 1956), 1377-8.

20 See for instance, John Nichols, The Progresses and Public Processions of Queen Elizabeth vol. 3 (London, 1823), 320-48; Desmond Sparling Bland (ed.), Three Revels from the Inns of Court (Amersham, England, 1984), 69-115. Bland's is the most comprehensive edition of the entertainment to date.

21 John Chamberlain remarked that 'I cannot call yt a maske seeing they were not disguised nor had visards' (qtd in Bentley, Jacobean and Caroline Stage, 1377). The 'law sports' were public activities in which the lawyers in training at the Inns of Court participated, including mock trials and speeches.

22 See Heaton for a more detailed description of these manuscripts. Selections from the antimasques involving Paradox and the Mountebanks were published with Sir Thomas Overbury His Wife (London, 1620 and reprints). For a list of documents relating to the revels (including fragments, excerpts, and comments), consult Nelson and Elliot, REED: Inns of Court, esp. p. 365, 488-99, 563-80, and 738-9. While the REED volume considers BL Add MS 5956 fragmentary, it contains all of the masque except for the 'framing songs' (which are not found in Huntington Library HM 21, another complete version of the masque), and one other song, 'The Hours of Sleepy Night', which is sung before the final parting song. See also C.E. McGee and John C. Meagher, 'Preliminary Checklist of Tudor and Stuart Entertainments: 1614-1625', Research Opportunities in Renaissance Drama 30 (1988), 17-128.

23 I have modernized the spelling of this speech, which is found in all four versions with only minor differences. I would like to thank Kirsten Inglis for sharing her notes on BL Add. Mss 5956, 10444, and 29481 as well as Bodleian Rawl. D Ms 1021. For Huntington ms HM 21, I rely on John Payne Collier's transcription in Inigo Jones ... and Five Court Masques (London, 1848). 
24 Nichols explains that his version is 'taken from a ms in the Harleian collection ... without date', 320 .

25 Newdigate volume, $\mathrm{f} 11 \mathrm{v}$. The verse that begins 'he cannot be truly wise' is included in the paradoxes in BL Add. ms 5956, f 83.

26 This paradox is not found in the full-text versions preserved in Gray's Inn Library Ms 29, Bodleian Rawl. D. Ms 1021, or BL Add. Ms 5956. They are not in Collier's edition (based on Huntington Ms HM 21) or Nichols's edition. Nor are they among the paradoxes printed with Overbury His Wife, nor in the paradoxes in Bodleian Sancroft ms 29 or Bodleian Ashmole ms 36, 37.

27 Newdigate volume, $\mathrm{f} 1 \mathrm{v}$.

28 Ibid, f 3.

29 Ibid, f 12.

30 There are three nineteenth-century editions of the play: John Nichols (ed.), The Progresses, Processsions, and Magnificent Festivities of King James the First, His Royal Consort, Family and Court... (London: 1828); J[ohn] Payne Collier (ed.), Five Court Masques; Edited from the Original Mss of Ben Jonson, John Marston, etc. (London, 1848), 111-30; and A.H. Bullen (ed.) The Works of John Marston, vol. 3 (Boston, 1887). For Collier's dubious treatment of Huntington Library ms HM 21 (including perhaps writing Marston's name on it) and deceptions surrounding this masque, see Albert H. Triconi's 'John Marston's Manuscripts', Huntington Library Quarterly 43.2 (1980), 87-102; see also Sydney Race, 'Collier and the Mountebank's Masque' Notes and Queries 197 (1952), 281-3. Bullen printed Collier's work, though he was hesitant about the ascription to Marston. Heaton explains that John Nichols, a nineteenth-century editor, used a now lost manuscript for his copy-text. Bland used Nichols's text as his copy-text and provides occasional manuscript variants, but his is not a comprehensive variorum edition. For more on these editions, including a criticism of Bland's edition, see Gabriel Heaton, 'Textual Reproduction in a Scribal Community', unpublished chapter from 'Performing Gifts: The Manuscript Circulation of Elizabethan and Early Stuart Courtly Entertainments', PhD thesis (Cambridge University, 2003). I would like to thank Gabriel Heaton for sharing this chapter of his thesis with me. The version of Heaton's chapter that I have is unpaginated.

31 Heaton, 'Performing Gifts'. Early reactions to this entertainment are catalogued in Bentley, Jacobean and Caroline Stage. The entertainment has also been briefly discussed by A. Wigfall Green in The Inns of Court and Early English Drama (1931, rpt New York, 1965), 117-21; Philip J. Finkelpearl in John Marston of the Middle Temple: An Elizabethan Dramatist in his Social Setting (Cambridge MA, 1969), 60; and Sarah Knight, "'He is indeed a kind of Scholler-Mountebank": Academic Liars 


\section{I34 Laura Estill}

in Jacobean Satire', Studies in Scams, Frauds, and Deceits (1300-1650), ed. Mark Crane, Richard Raiswell, Margaret Reeves (Toronto, 2004), 70-3. Other noteworthy scholarship on these entertainments is referenced in further notes.

32 As Alan H. Nelson and John R. Elliot (eds) point out, at times the Arbury version offers inferior readings to other versions of the play, REED: Inns of Court (Toronto, 2010), 365.

33 BL Add ms 5956, ff 77, 83, and 84 each begin separate lists of the 'masculine' paradoxes.

34 BL Add ms 5956, f 83.

35 Newdigate volume, ff 5v, 6v.

36 Ibid, $\mathrm{f} 1$.

37 Newdigate volume, $\mathrm{f} 2$.

38 Newdigate volume, f 8v.

39 Ibid, f 9.

40 Heaton, 'Performing Gifts', points out that while the copyist of the Newdigate manuscript added stage directions, the Huntington copyist excised as much stage business as possible.

41 Newdigate volume, f $6 \mathrm{r}-\mathrm{v}$.

42 Bodleian ms Rawl. D. 1021, f 9; Gray's Inn ms 29, f 23; Newdigate volume f 5v.

43 Ibid.

44 Quotations from Newdigate volume, ff 5v, 6v; the song also appears in Bodleian Ms Rawl. D. 1021 f 9v. This song does not appear in Gray's Inn ms 29.

45 As Bentley explains, 'only the Mountebanks' part of the entertainment ... was given at court', Jacobean and Caroline Stage, 1378.

46 Newdigate volume, $\mathrm{f} 7$.

47 Ibid, f 10v. This costume description is not found in Gray's Inn Ms 29, Bodleian Rawl. D. ms 1021, BL Add. ms 5956, Collier's edition (based on Huntington Ms HM 21) or Nichols's transcription.

48 Knight, "'He is indeed a kind of Scholler-Mountebank", 70, 72.

49 Newdigate volume, f 5v.

50 Bacon was not only present at this masque, he had been involved in other Gray's Inn revels (which, decades earlier, led his mother to write to Anthony Bacon, 'I trust that they will not mum, nor masque, nor sinfully revel at Gray's Inn' — though her letter had little effect on stopping the revels) (Bland, Three Revels, 76). Heaton, 'Performing Gifts', points out that Bacon wrote speeches for previous Christmas revels; see also Brian Vickers (ed.), Francis Bacon (Oxford, 1996), 532. A detailed guest list is not found in other known versions: Gray's Inn Ms 29, Bodleian Rawl. D. Ms 1021, BL Add. ms 5956, Nichols, or Collier. 
51 Pauline Croft, 'Howard, Thomas, first earl of Suffolk (1561-1626)', DNB (Oxford, 2004-).

52 Larminie, Wealth, Kinship and Culture, 116.

53 Ibid, 201-4.

54 Newdigate volume, f 13. The petition has been reprinted in Constitutional Documents of the Reign of James I, 1603-1625, ed. Joseph Robson Tanner (Cambridge, 1930), 280-3.

55 Larminie, Wealth, Kinship and Culture, 161.

56 Ibid, 157, 163.

57 Newdigate volume, f 26; Larminie notes that she finds this comment to be in Richard's handwriting in Wealth, Kinship and Culture, 161.

58 Newdigate-Newdegate, Cavalier and Puritan, 302. Richard II wrote disparagingly of the French in his diary while he toured France in the 1690s: 'Superstition, Nastiness, Supineness, Swearing, Sabbath-breaking (even Acting Plays, Carting, Buying and Selling on Sundays); Exacting on Strangers; ... their neglect of their Highways, but more of their Liberty and Property, shews the Proverb to be true, That the French King is Asinorum Rex' (Newdigate-Newdegate 336).

59 Newdigate volume, f 25.The full list of accusations can be read in The House of Lords Journals, vol. 11 (10 July 1663), available from British History Online, http://www .british-history.ac.uk/report.aspx?.compid=14361.

60 See The Diary of Samuel Pepys, available online, http://www.pepysdiary.com/ archive/1663/07/10/.

61 Newdigate volume, f 24.

62 Larminie, Wealth, Kinship and Culture, 190-1.

63 Richard wrote multiple letters to his son justifying his wish to refuse the title. Ibid, 190, esp. n 115.

64 Larminie, Wealth, Kinship and Culture, 191. Richard was granted the baronetcy 'with a discharge from all services that ought to be performed or sums to be paid in respect of the said dignity'. (S.P. Dom., Entry Book 40A, f 206. 22 June 1677. State Papers Online. Gale Document Number: MC4329000929.) See also S.P. Dom., Car. II. 395, No. 176. 11 August 1677. State Papers Online. Gale Document Number MC4329001397.

65 Newdigate volume, f 38.

66 Eton only has a complete record of students and masters after 1791, so it is not surprising that these names cannot conclusively be linked to the college. The neoLatin poets, however, might not have been students or masters: they could have been private tutors hired by families to accompany the students to school. If they were tutors, there would be no record of them, as they were not employed by the 
college. I would like to thank Penny Hatfield, archivist at Eton, for her help with this research.

67 'John Foxcroft', Clergy of the Church of England Database (CCED), CCED Person ID 44151. http://www.theclergydatabase.org.uk/. Another John Foxcroft was appointed curate of Nuneaton in 1719 (CCED Person ID 44150). According to the CCED, the Liptrott family similarly had early eighteenth-century members appointed to the clergy at Nuneaton. Another connection the Newdigates might have had to the neo-Latin poets is through John Parker. John Newdigates's aunt Mary (b. 1635) had married into the Parker family; Richard I, John's grandfather, could have counted the Parkers as part of his 'rich and solid network of kin and contacts' (Larminie, Wealth, Kinship and Culture, 139).

68 Newdigate volume, $\mathrm{f} 49 \mathrm{v}$.

69 Newdigate volume, f 69. The chorus of the song is 'With old Sir Symon the King etc'; 'Old Simon the King' is the tune of multiple ballads (see the University of California's English Broadside Ballad Archive, http://ebba.english.ucsb.edu).

70 For more information on the elections, see W.B. Stephens (ed.), 'The City of Coventry: Parliamentary Representation', A History of the County of Warwick: Volume 8: The City of Coventry and Borough of Warwick (Oxford, 1969), 248-55, also available at http://www.british-history.ac.uk. The song also refers to '[building] up a Brewhouse i' the City / Oh how they consulted a Plot', possibly referring to the Rye House Plot of 1683, a plot to assassinate both King Charles II and his brother James. There were dozens of ballads written about the Rye House Plot, many of which are collected in J. Woodfall Ebsworth (ed.), The Roxburghe Ballads vol. 5 (Hertford: 1885), esp. 257-509.

71 Newdigate volume, $\mathrm{f} 69$.

72 The Phanatick in His Colours Being a Full and Final Character of a Whig : in a Dialogue Between Tory and Tantivy (London, 1681).

73 Larminie, Wealth, Kinship and Culture, 139.

74 See George F. de Lord's Poems on Affairs of State: Augustan Satirical Verse, 16601714 (New Haven \& London, 1963).

75 Newdigate volume, f 50 . The manuscript contains a few variants from the print version. The most notable variant is at line 39-40. Line 37 begins, 'Muscovy sells us hemp and pitch and tar / Iron and copper Sweden, Münster war', and in many versions continues, 'Ashley prize, Warwick, customs; Cart'ret pay; / But Coventry sells the whole fleet away'. In Arbury Hall ms 414, the lines run 'Ashly prize, Warrick customes, Carteret / sells pay, but Coventry doth sell the fleet' (f 50v), a variation which maintains the meaning and meter but changes the rhyme: this is possibly an example of a copyist editing while re-copying, or an act of memorial reconstruction. 
76 Nigel Smith (ed.), The Poems of Andrew Marvell (London and New York, 2003), 327-8.

77 For a clarification of the separate poems, see Osborne, Advice-to-a-Painter Poems 1633-1856: An Annotated Finding List (Texas, 1949). The poem in the Newdigate volume begins 'Painter once more thy Pencill reassume / And draw me in 'one'ane scene London \& Rome' (f 56). The other poems not to be confused with this one are The Third Part of the Advice to the Painter (1684), which begins 'Painter once more thy Pencil Reassume, / and in a Lanskip draw me Christendom' (Osborne poem 33) and New Advice to a Painter (1679/80), which begins 'Painter, once more thy Pencil reassume, / Draw me a Night Piece - Draw me Rome' (Osborne poem 27).

78 Osborne, Advice-to-a-Painter Poems, 38. For further examples of manuscripts that contain this poem, see Margoliouth (esp. 376) and the Union First Line Index of Manuscript Verse, bearing in mind that three poems share the same first line.

79 Newdigate volume, f 63.This satiric litany was first published as a broadside (Oxford, [1688]) republished in Poems on the Affairs of State, the Second Part (London, 1697), 83-6 and in A Supplement to the Collection of Miscellany Poems Against Popery \& Slavery (London,1689), 1-5.

80 The Newdigate compiler helpfully notes the source text, 'The Paper that this is a Copy of was written on, this, Imprimatur. Obadiah Walker. Oxford Printed by $\mathrm{H}$. Cruttenden one of His Majesties Printers' (f 63v).

81 Ibid, $\mathrm{f} 63$.

82 Ibid, f 63v.

83 Larminie, Wealth, Kinship and Culture, 165.

84 Mark Knights, Politics and Opinion in Crisis, 1678-81 (Cambridge, 1994), 111.

85 Newdigate volume, f 67. The poem was first published in Miscellany, Being a Collection of Poems by Several Hands, by François La Rochefoucauld and edited by Aphra Behn (London, 1685). The poem appears in only one other known manuscript, University of Leeds Brotherton Ms Lt 109 (p. 1-3), available through Literary Manuscripts: 17th and 18th Century Poetry from the Brotherton Library, University of Leeds.

86 Newdigate volume, f $67 \mathrm{v}$.

87 Ibid, f 68.

88 Ibid, f 68.

89 'In the Praise of Folly' includes another underline that points the reader to a marginal notation. This underline is found where the speaker criticizes the ape-like unenlightened man who 'requires no wit, to make him wise'; the comparison is to a fish that 'having hid her head / sees not herself' ( $\mathrm{f} 67 \mathrm{v}$ ). The copyist offers an alternative reading for the underlined words: worse than a fish who has hid her head, 
the line could read 'never shows' her head (marginal notation), which precludes all possibility of self-understanding even in the future.

90 Ibid.

91 For more information on the Newdigate newsletters, see Newdigate-Newdegate's Cavalier and Puritan, which includes transcriptions of various letters; see also Knights. Philip Hines Jr edited and digitized the first 2100 newsletters (1674-1692). The Newdigate newsletters are held at the Folger Shakespeare Library in Washington.

92 Newdigate-Newdegate suggests as much in Cavalier and Puritan: 'Sir Richard Newdigate, with his pronounced opinions and well-known championship of the form of faith upheld by Monmouth, could hardly have escaped being a marked man at the time of the risings in England and Scotland', 263.

93 The Genius of True English=Men (London, 1680); Poems on Affairs of State, the Second Part (London, 1697), 37-8, EEBO. Newdigate volume, f 66.

94 See Keith Walker and Nicholas Fisher (eds), John Wilmot, Earl of Rochester: The Poems and Lucina's Rape (Malden MA and Oxford, 2010), 157-8. See also Harold Love (ed.), The Works of John Wilmot, Earl of Rochester (Oxford, 1999) 257-8, 662-3.

95 Newdigate volume, f 66.

96 Ibid. Though I have not been able to consult all extant versions of this poem, in the versions I have consulted, the 'hate change' variant is unique to the Newdigate volume. The versions that include the typical 'hate chains' reading include the Longleat Harbin ms (used as a copy-text by Walker and Fisher), National Library of Scotland Advocate's Ms 19.1.12, BL Add. Mss 29497 and Harley 6913, and, in print, Wing G0518, M3140, P2720, and R1758.

97 Walker and Fisher, John Wilmot, 158.

98 Newdigate volume, f 60 . A copy of the poem (as written in the Newdigate volume) decorates a French print from 1690 that depicts the alleged death of William III (BM Satires 1242; Registration Number 1862, 1011.800). A different version (with changes in stanza order, different lines, and alternative wording) was published in 1714 in Oeuvres Diverses Du Sieur D**, vol. 2 (Amsterdam, 1714), 351.

99 Newdigate-Newdegate, 312-28.

100 See Roxburghe II.386 (available from the English Broadside Ballad Archive, http:// ebba.english.ucsb.edu); Pepys IV.370; Douce II.171v, (available from Bodleian Library Broadside Ballads, http://www.bodley.ox.ac.uk/ballads), and the multiple versions on ЕЕВO. A longer version of this poem (London, 1693) was advertised as Doctor Popes Wish. The Only Correct and Finish'd COPY: Never before PRINTED. Like the additional verse in the Newdigate volume, this longer version includes a 
verse wishing for a life untroubled by politics, 'Nor Tory, or Whig, nor Observator, or Trimmer / May I be, nor against the Laws Torrent a Swimmer' (1, verse 5). 'The Old Man's Wish' was printed in Poems on Affairs of State from 1640 to this present year 1704, (London, 1704), 393-4 (ECCO). Poems on Affairs of State: The Second Part (London, 1697) includes other satiric poems that are sung to the tune of 'The Old Man's Wish', such as 'The Pope's Wish' (30). 'The Old Man's Wish' was later reprinted in John Dryden's The First Part of the Miscellany Poems, vol. 3 (1716), 178-9; an even later broadside, available from ECCO, dates from around 1740 .

101 Anthony Wood, 'Walter Pope', Athenae Oxoniensis, 3rd ed., ed. Philip Bliss (London, 1820), 4.725 .

102 Newdigate volume, f 64 .

103 Robert Willman, in "The Origins of "Whig" and "Tory" in English Political Language', The Historical Journal 17 (1974), 262, suggests that L'Estrange was the first to envision politics as a dialogue between Whigs and Tories.

104 A Sermon Prepared to be Preach'd at the Interment of the Renowned Observator (1682), 10, quoted in Mark Goldie, 'Roger L'Estrange's Observator and the Exorcism of the Plot', Roger L'Estrange and the Making of Restoration Culture, ed. Anne Dunan-Page (Aldershot, England, 2008), 67.

105 Newdigate volume, f 64.

106 The print versions cited in note 100 agree on this chorus.

107 'To the Observator', Poems on Affairs of State: The Second Part (1697), 190-1.

108 Martin Dzelzainis, 'L'Estrange, Marvell and the Directions to a Painter: The Evidence of Bodleian Library ms Gough London 14', in Anne Dunan-Page (ed.) Roger L'Estrange and the Making of Restoration Culture (Aldershot, England, 2008), 5366, esp. 57.

109 Quoted in Dzelzainis, 'L'Estrange, Marvell and the Directions', 58. For more on the publication of manuscript libels, see Harold Love's English Clandestine Satire, 1660-1702 (Oxford, 2004); for the circulation of libels in earlier manuscripts, see Alastair Bellany and Andrew McRae (eds), 'Early Stuart Libels: An edition of poetry from manuscript sources', Early Modern Literary Studies Text Series I (2005) http:// purl.oclc.org/emls/texts/libels/.

110 Wood, Athenae Oxoniensis, 4.725. Another manuscript that contains this additional verse is Sarah Cowper's commonplace book, Hertfordshire Archives D/EP F37, 228; for more on Cowper's manuscript, see The Perdita Project. Folger V.b. Ms 94 also includes a copy (p. 121). No other versions are catalogued in the Union First Line Index of Manuscript Verse.

111 Cartwright's poem was originally published as a broadside in 1647, beginning 'Thou sun that shed'st'. Samuel Shepard included the first eight lines in Epigrams 
Theological, Philosophical, and Romantick (London, 1651). The first line was changed to 'Thou sun that shew'st' when it was republished in 1671 as November, or Signal Days. This version was in turn republished as Verses Made Upon the Several Festivals of November and Remarkable Days in the Whiggish-Calendar (np, 1685), printed under the pseudonym Merlynnius Redivivus. The additional verse is not found in Literature Online nor in the manuscript sources listed in the Folger Union First Line Index.

112 Newdigate volume, f 59.

113 Arthur F. Marotti, Manuscript, Print, and the English Renaissance Lyric (Ithaca NY, 1995), 136-208, esp. 171-208.

114 Newdigate volume, f 59.

115 Ibid.

116 Thanks to Owen Stockden who pointed out the dates of Catherine's illness in his edition of the poem for the Arbury/Osborne research team.

117 Newdigate volume, f 65.

118 The two lines 'Whose glorie is to be as she was made / Without black patches help or pencills shade' are written in the left-hand margin, perpendicular to the rest of the poem. Their placement in the poem is indicated by the use of two circles as a dagger.

119 Newdigate volume, f 70 .

120 For more on anti-cosmetic texts in the early modern period, see Patricia Phillippy's Painting Women: Cosmetics, Canvases \& Early Modern Culture (Baltimore, 2006).

121 Jacqueline Jenkins and Mary Polito (eds), The Humorous Magistrate [Osborne Edition], Malone Society (Manchester, 2011), 11 764-6.

122 See Faber's article in this journal. A version of 'When First King Henry Ruled the Land', appears in the Ampleforth Play. The Ampleforth play, as Cecil Sharp presents it, is an amalgam of literary and traditional texts and includes a large portion of the wooing scene from William Congreve's Love for Love (1695), and so is of dubious origins. Steve Roud and Paul Smith, 'James Madison Carpenter and the Mummers' Play', Folk Music Journal 7 (1998), 496-513.

123 The version of the poem in the Newdigate volume is not the version most often found in printed collections ('When first King Henry ruled this land / He was a right generous King' or the related twelve-line 'King Stephen was a worthy king, / As ancient bards do sing'). The Arbury version is:

When first King Arthor Rul'd this Land,

That great and mighty King;

Hee bought five blocks of Barly flower

To make a bagg-pudding. 
A bagg-pudding, then he did make

And stufft it well with plomb's

He put into't heuge Gobbs of ffatt

As bigg as both my Thombs

Then call'd he up his merry men all

They came in sworm's like Bee's

Each man was Clad in Coate of buffs

As thick a Ches-shire Cheese

They all gan draw their Winniard's out

No Grace they said yat day

But fell to work on Goosberry foole

Or what stood in their way.

Then, Chopp's work'd harde, like peppermills

The Victules to Devouer

For all was gone both Tarte, \& Cake

In quarter of an houre.

For a list of other sources and variations, see Iona Opie and Peter Opie (eds), The Oxford Dictionary of Nursery Rhymes (Oxford, 1995), 56-7. For a tune to this nursery rhyme, see Anne G. Gilchrist's 'The'Owd Lass of Coverdill: And other SwordDance Fragments', The Journal of the English Folk Dance Society 2 (1928), 31-4. I was unable to consult the version of this poem in Harvard MS ENG 1497 (vol. 2, f 97).

124 Newdigate volume, $\mathrm{f} 75$.

125 John Nichols, Queen Elizabeth's Progresses, vol. 4, part 1 (London, 1821), 1-18. One version of the entertainment is held at the Warwickshire County Record Office, CR 136/B2454 and B255.

126 Gabriel Heaton, Writing and Reading Royal Entertainments (Oxford, 2010), 109-10. Larminie, Wealth, Kinship and Culture, 83.

127 Scholars who do not include the complaint in the text of the entertainment include Heaton as well as Robert Krueger (ed.), The Poems of John Davies (Oxford, 1975), 425. The grounds for excluding the complaint from the entertainment are solid. Nichols included the complaint in the entertainment based on Ralph Churton's eighteenth-century transcription of the manuscript in the Newdigate archive, even though Churton explained that "This "Complaint" is on a separate leaf, and seems to be in a different hand' (qtd in Krueger 425). The complaint is not found with the version of the entertainment in Folger Ms X.d.172; furthermore, the version of the 
complaint in BL Harley Ms 3910 (f 38v) does not include a mention of the entertainment.

128 For details of the theatrical updates in the newsletters, there are a series of articles from Theatre Notebook: see John Harold Wilson's 'Theatre Notes from the Newdigate Newsletters' 15 (1961), 79-84 and his 'More Theatre Notes from the Newdigate Newsletters' 16 (1961-62), 52. See also Philip Hines Jr's 'More Theatre Items from the Newdigate Newsletters' 49 (1995), 91-8 and his 'New Theatre Items from the Newdigate Newsletters' 56 (2002), 143-55.

129 Jeffrey Todd Knight, 'Fast Bind, Fast Find: The History of the Book and the Modern Collection’, Criticism 51 (2009), 83.

130 Siobhan Keenan, 'Staging Roman History, Stuart Politics, and the Duke of Buckingham: The Example of The Emperor's Favourite' (this issue) and Mary Polito and Jean-Sébastien Windle, “You See the Times are Dangerous": The Political and Theatrical Situation of The Humorous Magistrate (1637)', Early Theatre 12 (2009), 93-118. Another early modern manuscript in the Arbury archive that physically joins the theatrical and the political is A415, which contains a copy of Thomas Goffe's The Raging Turk or Bajazet the Second bound with a political newsletter from 1620s Spain. A415 contains Richard II's bookplate and is dated 1709.

131 For a discussion of full-text plays in manuscript, see Paul Werstine, 'Plays in Manuscript', John D. Cox and David Scott Kastan (eds), A New History of Early English Drama (New York, 1997), 481-97 and William B. Long, "Precious Few”: English Manuscript Playbooks', David Scott Kastan (ed.), A Companion to Shakespeare (Malden MA and Oxford, 1999), 417-33. For a discussion of the Arbury and Osborne versions of The Humorous Magistrate, see Kidnie, 'Near Neighbours: Another Early Seventeenth-Century Manuscript of The Humorous Magistrate', English Manuscript Studies, 1100-1700 13 (2007), 187-211. See also Julie Sanders, The Cultural Geography of Early Modern Drama, 1620-1650 (Cambridge, 2011), esp. 110-15.

132 This list builds on the microfilm contents by the archivist, updated by Johnstone, and the table of contents appended to Kidnie's Introduction.

133 'French' may have been added to the title later.

134 For a complete family tree, see Larminie, Wealth, Kinship and Culture, Appendix 4 , esp. $210-11$. 